\title{
PENDEKATAN MULTIPLE INTELLIGENCE PADA PEMBELAJARAN PENDIDIKAN JASMANI UNTUK HIDUP SEHAT DI SEKOLAH DASAR
}

\author{
TARYATMAN $^{1}$, SITI IRENE ASTUTIDWININGRUM ${ }^{2}$ \\ Program Studi Pendidikan Dasar \\ ${ }^{1}$ Universitas Sarjanawiyata Tamansiswa, ${ }^{2}$ Universitas Negeri Yogyakarta \\ taryatman@ustjogja.ac.id,ireneast@yahoo.com
}

\begin{abstract}
Abstrak
Berdasarkan teori perkembangan peserta didik, diyakini bahwa setiap peserta didik lahir dengan lebih dari satu bakat. Setiap peserta didik mempunyai bakat yaitu kemampuan yang menonjol dalam salah satu aspek kepribadian, yang diperoleh sebagai pembawaan. Oleh karena itu, sejak lahir setiap peserta didik tidak ada yang bodoh, yang ada anak yang cerdas dalam aspek yang berbeda-beda. Kajian literatur ini terfokus pada pendekatan kecerdasan majemuk pada pembelajaran pendidikan jasmani untuk hidup sehat bagi peserta didik Sekolah Dasar. Pembahasan dalam kajian telaah ini supaya memberikan gambaran sejumlah strategi bagi guru pendidik jasmani untuk kegaitan belajar mengajar (1) teknik gerak dasar; (2) hubungan antara hidup sehat yang aktif, teori multiple intelligence, dan pembelajaran gerak lokomotor, gerak non lokomotor, dan gerak manipulatif (3) pendekatan Multiple Intelligence untuk mengajar dan belajar. Teori Multiple Intelligence menyatukan sumber daya intelektual dan bervariasi yang diberikan kepada peserta didik dan masyarakat dilingkungan sekolah maupun masyarakat umum. Mengintegrasikan teori Multiple Intelligence dengan prinsip-prinsip hidup sehat secara aktif yang dipelajari sebagai cara untuk perencanaan program, penyampaian program, pembelajaran peserta didik, dan untuk memfasilitasi evaluasi pembelajaran yang sesuai dalam program hidup sehat bagi peserta didik di sekolah dasar.
\end{abstract}

Kata kunci:Multiple Intelligence, Pendidikan Jasmani, Hidup Sehat

\section{MULTIPLE INTELLIGENCE APPROACH IN JASMANI EDUCATION LEARNING FOR HEALTHY LIVING IN ELEMENTARY SCHOOL}

\begin{abstract}
Humans have diverse feelings, minds, characters or characters, all of which are actually various forms of intelligence. Based on student development theory, it is believed that each student is born with more than one talent. Every student has a talent that is the ability that stands out in one aspect of personality, which is acquired as a trait. Therefore, from birth every student is not stupid, there are intelligent children in different aspects. This literature review focuses on the Multiple Intelligence approach to learning physical education for healthy living for elementary school students. The discussion in this study is to give an overview of a number of strategies for physical education teachers for teaching and learning activities (1) basic motion techniques; (2) the relationship between active healthy living, Multiple Intelligence theory, and locomotor, non-locomotor and manipulative basic motion learning, and (3) Multiple Intelligence approaches for teaching and learning. The Multiple Intelligence theory brings together intellectual and varied resources provided to students and the community in the school environment and the general public. Integrate Multiple Intelligence theory with the principles of active healthy
\end{abstract}


living that are learned as a way for program planning, program delivery, student learning, and for facilitating the evaluation of learning that is appropriate in a healthy living program for students in primary schools.

Keywords: Multiple Intelligence, Physical Education, Healthy Life

\section{PENDAHULUAN}

Intelligence telah diteliti selama bertahun-tahun dan merupakan istilah abstrak. Karena itu selalu bertanya-tanya dan penelitian telah dilakukan untuk menentukan batas-batas dan karakteristik sebagai makhluk hidup (Bumen, 2005). Jadi, Intelligence dijelaskan oleh pendidik sebagai kemampuan untuk belajar, oleh para ahli biologi sebagai kemampuan untuk beradaptasi dengan lingkungan, oleh psikolog sebagai kemampuan untuk mencapai kesimpulan oleh penalaran, oleh para ilmuwan komputer sebagai kemampuan untuk memproses informasi (Armstrong, 2000; Gunce, 1973).

Pendidikan berperan dalam memajukan dan mengembangkan suatu bangsa. Melalui pendidikan, manusia dapat mengembangkan potensi yang ada pada dirinya. Manusia dibekali perasaan, akal budi, karakter atau watak yang berbeda-beda satu dengan yang lainnya. Kecerdasan merupakan kemampuan untuk menyelesaikan persoalan dan menghasilkan produk dalam suatu setting yang bermacam-macam dan dalam situasi nyata (Ula, 2013, p. 82). Setiap peserta didik terlahir membawa potensi yang diwariskan dari generasi sebelumnya. Potensi sebelumnya adalah faktor keturunan (heredity factor) yang merupakan kemampuan awal yang dimiliki oleh setiap individu yang baru dilahirkan untuk beradaptasi dengan lingkumgan agar dapat berkembang secara optimal. Potensi bawaan perlu dikembangkan melalui berbagai stimulasi dan upaya-upaya lingkungan (Sugiarto, 2007).

Banyak peserta didik memiliki talenta (gift) yang tidak mendapatkan reinforcement di sekolahnya. Banyak sekali peserta didik yang pada kenyataannya dianggap sebagai peserta didik yang "Learning Disabled" atau ADD (AttentionDeficit Disorder), atau Underachiever, pada saat pola pemikiran mereka yang unik tidak dapat diakomodasi oleh sekolah (Susanto, 2005). Potensi ini dikembangkan secara bertahap dan integral dalam setiap usia sesuai dengan tahapan tumbuh kembang peserta didik, harapannta akan lahir penerus-penerus bangsa, yang beriman dan bertakwa kepada Tuhan Yang Maha Esa, berakhlak mulia, berkepribadian luhur, sehat, berilmu, cakap, kritis, kreatif, inovatif, mandiri, percaya diri, dan menjadi warga negara yang demokratis dan bertanggung jawab (Undang-Undang RI Tentang Pendidikan, 2007).

Berdasarkan teori perkembangan peserta didik yang telah dijelaskan sebelumnya, pada dasarnya setiap peserta dilahirkan dibekali dengan lebih dari satu bakat. Setiap peserta didikmempunyai bakat yaitu kemampuan yang menonjol dalam salah satu aspek kepribadian, yang 
diperoleh sebagai pembawaan. Gardner (1987) menyebut sebagai kecerdasan. Sembilan macam kecerdasan menurut Howard Gadner yaitu: kecerdasan linguistic, kecerdasan logika, kecerdasan musikal, kecerdasan kinestetik, kecerdasan visual, kecerdasan interpersonal, kecerdasan intrapersonal, kecerdasan naturalistic, kecerdasan eksistensi (Ula, 2013, p. 176).

Teori Kecerdasan beberapa dianggap sebagai kemampuan yang dimiliki untuk memecahkan masalah yang berbeda yang dihadapi individu.Dengan kata lain; setiap orang mungkin memiliki setiap jenis kecerdasan untuk tingkat tertentu (Cifuentes dan Hughey, 2003). Menurut Teori Kecerdasan Multiple;Belajar semua orang dengan alasan yang berbeda, kecepatan yang berbeda dan metode yang berbeda. Hal ini cukup bagi seorang guru untuk mengambil fakta iniuntuk membuat perubahan besar dan mempengaruhi banyak variabel. Praktek mengajar teori memfasilitasi peserta didikuntukbelajar dan memungkinkan peserta didikuntuk mengenal dirinya, kepercayaan pada diri mereka sendiri, untuk menghormati perbedaan individu, untuk meningkatkan gaya berpikir kreatif dan berpikir tentangpekerjaan masa depan (Bumen, 2005).

Guru-guru pendidikan jasmani di sekolah dasar perlu memahami konsep kecerdasan majemuk sehingga dapat mendorong peningkatan kesehatan peserta didik melalui pembelajaran pendidikan jasmani di sekolah. Karena dalam menjalakan profesinya sebagai guru pendidikan jasmani yang pada dasarnya memiliki karakter yang unik, yang menggunakan raga sebagai alat untuk belajar.

Proses belajar mengajar dalam pendidikan jasmani berbeda pelaksanaannya dari proses belajar mengajar mata pelajaran lain. Pedidikan jasmani merupakan pendidikan melalui aktifitas fisik. Samsudin (2008) “dengan berpartisifasi dalam aktifitas fisik, peserta didik dapat menguasai ketrampilan dan pengetahuan, mengembangkan apresiasi estetis, mengembangkan keterampilan genetik serta nilai sikap yang positif, dan memperbaiki kondisi fisik untuk mencapai tujuan pendidikan.”Teori Gardner Multiple Intelligence (teori MI) (Gardner, 1985) dapat dianggap sebagai (1) sebagai penggerak dengan mengaktifkan peserta didik untuk mengembangkan pengetahuan, kompetensi, dan penghargaan terkait dengan hidup aktif yang sehat, (2) sebagai daya tarik lembaga yang ada di sekolah dasar untuk bersama-sama mempromosikan hidup aktif yang sehat. Lembaga yang ada di lingkungan sekolah maupun di masyarakat, baik guru-guru, orang tua harus sering dilibatkan dalam kegiatan pembelajaran. Sebagai peserta didik harus mulai mengenal dan mempelajari aspek yang berbeda dari kesehatan dan aktivitas fisik, mereka mulai mengeksplorasi hubungan mereka ke layanan masyarakat, kebijakan dan program pemerintah, dan sosial tertentu / nilai-nilai budaya sekolah. Alternatif dan bervariasi sosial pergaulan sebagaipandangan budaya menambah kedalaman dan luasnya untuk mempelajari hidup aktif yang sehat. 


\section{METODE}

Penelitian yang penulis lakukan ini termasuk jenis penelitian kajian literatur dengan mencari sumber teori yang relevan dengan menemukan kasus atau permasalahan. Creswell, John. W.(2014; 40) menyatakan bahwa kajian literatur adalah ringkasan tertulis mengenai artikel dari jurnal, buku, dan dokumen lain yang mendeskripsikan teori serta informasi baik masa lalu maupun saat ini mengorganisasikan pustaka ke dalam topik dan yang membutuhkan dokumen.

Penulis menggunakan jenis data studi literatur dalam penelitian ini. Studi literatur merupakan cara yang digunakani untuk mengumpulkan data-data atau sumber-sumber yang berhubungan dengan topik dalam suatu penelitian. Data-data yang sudah diperoleh kemudian dianalisis dengan metode analisisdeskriptif. Metode analisis deskriptif dilakukandengan cara mendeskripsikan faktafakta yangkemudian disusul dengan analisis, tidak sematamata menguraikan, melainkan juga memberikanpemahaman dan penjelasan secukupnya.

\section{PEMBAHASAN}

Dalam artikel ini, penulis akan menyampaikan (1) kerangka kerja untuk hidup aktif yang sehat, (2) deskripsi ringkasan tujuh kecerdasan Gardner, dan (3) contoh cara teori MI meningkatkan hubungan disiplin, praktik pembelajaran, dan hasil belajar peserta didik terkait dengan pengetahuan, keterampilan, dan sikap yang berkaitan dengan hidup aktif yang sehat. Sebelum kita membahas aplikasi dari pendekatan pembelajaran Multiple Intelligence kita mengeksplorasi komponen utama yang berkontribusi terhadap hidup aktif yang sehat. Kami juga mengidentifikasi hambatan umum dan alamat pertanyaan biasanya bertanya.

\section{Pola hidup aktif yang sehat}

Hidup aktif yang sehat menghasilkan kesehatan peserta didik dalam banyak kegiatan akademik sekolah. Guru, sekolah, masyarakat, dan orang tua harus merampingkan dan mengkoordinasikan berbagai layanan dan program-program yang diperlukan untuk merespon kebutuhan kesehatan pesertadidikyang berbeda. Mutu kesehatan sekolah dan kualitaspendidikan jasmani dimaksudkan untuk bekerja secara sinergis untuk mempromosikan hidup aktif yang sehat, sementara obesitas, kebiasaan makan yang buruk, tidak aktifberolahraga, penyalahgunaan zat dan praktik seksual berisiko telah menempatkan kesehatan banyak peserta didik dalam bahaya (lihat gambar 1). 


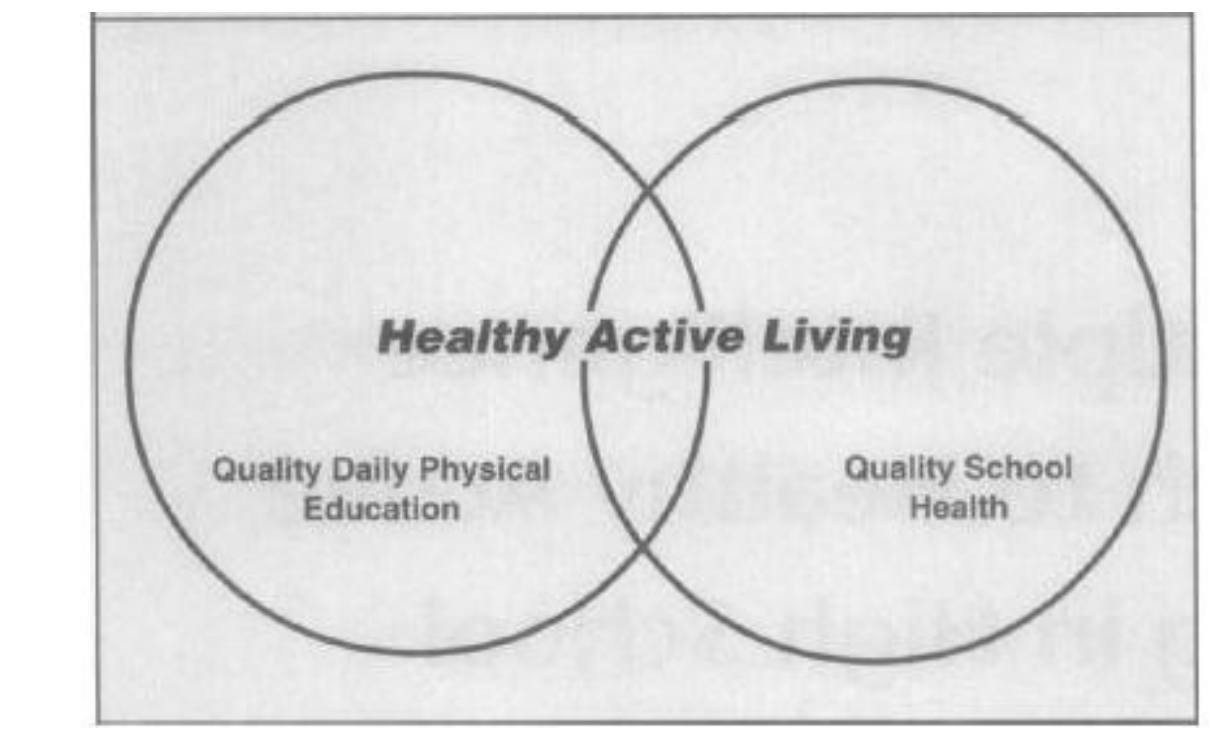

Gambar 1. Dua komponen program utama dari kehidupan aktif yang sehat (Andy Anderson a \& Ellen Weber, 1997)

\section{Program kesehtan sekolah yang sehat}

Program kesehatan sekolah yang berkualitas mengintegrasikan layanan kesehatan dan masyarakat dengan kebutuhan peserta didik dan lingkungan di mana peserta didik dan guru hidup, belajar, dan kerja. Kesehatan sekolah yang berkualitas (QSH) adalah program bersama-sama mempunyai empat komponen dasar: kurikulum pendidikan kesehatan (intra dan ekstra), layanan dukungan bagi para peserta didik, dukungan sosial, dan lingkungan fisik yang sehat. Kebijakan, program, layanan, dan kegiatan dibuat dalam kerangka ini adalah tanggung jawab peserta didik, guru, orang tua, layanan kesehatan dan sosial, lembaga, instansi, dan pemerintah.

\section{Pendidikan Jasmani yang berkualitas}

Kurikulum pendidikan jasmani bisa dijadikan sebagai komponen berkualitas dalam pembelajaran sehari-hari, jadi sekolah dapat menyediakan fasilitas dan layanan untuk peserta didiknya. Dilihat dari program pendidikan jasmani yang berkualitas memberikan perencanaan yang seimbang untuk para peserta didik, program pengajaran,dan aktivitas fisik untuk semua jenjang yang ada di sekolah dasar. Pendidikan jasmani yang berkualitas menargetkan pemahaman, kompetensi, indikator, dan hasil yang memungkinkan peserta didik mampu memecahkan masalah secara bersama-sama, sesuai dengan minat dan kemampuan mereka sendiri agar dapat menerapkan kebiasaan hidup aktif di dalam kehidupan sehari-hari.

Sekolah harus menyediakan fasilitas yang menyenangkan bagi peserta didik untuk ikut kegiatan latihan kepemimpinan, tempat bermain bersama-sama dan bersenang-senang. Peserta didik berpartisipasi dalam berbagai kegiatan, rekreasi, dan kegiatan yang berhubungan dengan berolahraga. Dari aktivitas tersebut harapannya peserta didik dapat melatih mental dan interaksi sosialnya baik dengan teman sebaya, guru, maupun lingkup masyarakat. 
Guru pendidikan jasmani harus mengajarkan komponen yang paling dasar yaitu fundamental gerak dasar terhadap peserta didiknya. Dimana program ini cocok dengan gagasan hidup aktif yang sehat. Fundamental gerak yang diajakan adalah gerak dasar lokomotor, non lokomotor, dan manipultif. Peserta didik dikenalkan dengan cara berjalan, berlari, bergerak ditempat dengan berbagai variasi gerakan dan menggunakan alat yang telah dimodifikasi untuk memaksimalkan potensi fisik, emosional, sosial, intelektual, dan spiritual peserta didik.

Teori Multiple Intelligence Gardner (teori MI) memperluas persepsi guru dan peserta didik tentang apa artinya menjadi cerdas. Dengan menawarkan rentang yang lebih besar pilihan untuk mengajar konten dan memperluas jumlah cara peserta didik dapat mengekspresikan dan memahami materi pelajaran. Menurut Gardner Intelijen adalah kemampuan untuk mengkoordinasikan pikiran dan tindakan dalam kaitannya dengan memecahkan masalah. Menurut teori Gardner, kecerdasan mencakup kemampuan untuk membuat dan menyelesaikan masalah, membuat produk atau menyediakan layanan yang dihargai dalam suatu budaya atau masyarakat. Point utamadariteori Gardner yaitu:

a. Semua manusia memiliki kesembilan kecerdasan dalam berbagai tingkatan.

b. Setiap individu memiliki profil kecerdasan yang berbeda.

c. Pendidikan dapat ditingkatkan dengan menilai profil kecerdasan peserta didik dan merancang kegiatan demikian.

d. Setiap kecerdasan menempati area otak yang berbeda.

e. Kesembilan kecerdasan dapat beroperasi satu sama lain.

f. Sembilan kecerdasan ini dapat menentukan jenis manusia.

\section{Delapan Kecerdasan Gardner}

1. Kecerdasan Linguistik. Kecerdasan verbal / linguistik mengacu pada kemampuan individu untuk memahami dan memanipulasi kata-kata dan bahasa Kemampuan menggunakan kata secara efektif, baik secara lisan (misalnya, pendongeng, orator, atau politisi) maupun tertulis (misalnya, sastrawan, penulis drama, editor, wartawan). Guru dapat meningkatkan kecerdasan verbal / linguistik peserta didik dengan melatih mereka membuat catatan kecil setelah pembelajaran, memainkan permainan kata-kata dan berdiskusi. Peserta didik melakukan interprestasi secara tulisan maupun lisan dengan menceritakan dari pembelajaran gerak dasar lokomotor, non lokomotor, dan manipulatif.

2. Kecerdasan Matematis-Logis. Kemampuan menggunakan angka dengan baik (misalnya, ahli matematika, akuntan pajak, ahli statistik) dan melakukan penalaran yang benar (misalnya, sebagai ilmuwan, pemrogram komputer, atau ahli logika. Guru dapat meningkatkan kecerdasanmatematis-logis peserta didik dengan melatih mereka untuk mempraktikan gerak 
dasar lokomotor seperti berjalan, berlari, melompat, meluncur, dan mereka mencatat jarak tempuh yang telah mereka praktikkan.

3. Kecerdasan Spasial. Kemampuan memersepsi dunia spasial-visual secara akurat (misalnya, sebagai pemburu, pramuka, pemandu) dan mentranformasikan persepsi dunia Spasialvisual tersebut (misalnya, "dekorator interior, arsitek, seniman, atau penemu). Kecerdasan ini juga meliputi kepekaan pada warna, garis, bentuk ruang dan hubunean antar unsur tersebut. Guru dapat meningkatkan kecerdasan ini dengan melatih peserta didik untuk menceritakan kembali materi gerak lokomotor, non lokomotor, dan manipulatif melalui imajinasi mereka. Mengembangkan desain lapangan atau halaman sekolah untuk praktik pembelajaran pendidikan jasmani.

4. Kecerdasan Kinestetis-Jasmani. Merupakan keahlian menggunakan seluruh bagian tubuh untuk menerapkan ide dan perasaan (contoh, sebagai aktor, pemain pantomim, atlet, atau penari) dan ketrampilan menggunakan tangan untuk menciptakan atau mengubah sesuatu (misalnya, sebagai perajin, pematung, ahli mekanik, dokter bedah). Guru pendidikan jasmani dapat menjelaskan gerakan tubuh yang mempengaruhi gerak dasar lokomotor, non lokomotor, dan manipulatif. Guru dapat melakukan beberapa variasi gerakkan yang kemudian peserta didik menirukan, setelah itu identifikasi indikator kinerja untuk membuat evaluasi pencapaian pembelajaran. Berdiskusi bagaimana setelah pembelajran gerak dasar dapat dipraktikan diluar sekolah.

5. Kecerdasan Musikal. Merupakan kemampuan menangani bentuk-bentuk yang berhubungan dengan musikal, dengan cara memersepsi (misalnya, sebagai penikmat musik), membedakan (misalnya, sebagai kritikus musik), menggubah (misalnya, sebagai komposer) dan mengekspresikan (misalnya, sebagai penyanyi).Guru dapat meningkatkan kecerdasan ini dengan melatih peserta didik bermain peran yang diikuti dengan musik yang menggambarkan permainan itu sendiri. Atau peserta didik menciptakan lagu yang mereka gemari yang dapat disesuaikan dengan pembelajaran.

6. Kecerdasan Interpersonal. Kemampuan memersepsi dan membedakan suasana hati, maksud, motivasi, serta perasaan orang lain.Guru pendidikan jasmani dapat meningkatkan kecerdasan interpersonal dengan cara bagaimana peserta didik mampu menciptakan kerjasama antara teman sebaya. Membuat poster untuk mempromosikan hidup sehat yang baik, dan mengajak untuk rajin berolahraga yang bermanfaat untuk fisik dan menjaga interaksi social dengan orang lain.

7. Kecerdasan Intrapersonal. Kemampuan memahami diri sendiri dan bertindak berdasarkan pemahaman tersebut. Untuk menunjukkan kekuatan dalam Kecerdasan Intrapersonal, peserta 
didik harus dapat memahami mereka memiliki emosi, motivasi, dan sadar akan kekuatan dan kelemahan mereka sendiri. Guru dapat menetapkan kegiatan reflektif, seperti menulis catatan untuk membangkitkan kecerdasan intrapersonal peserta didik. Penting untuk dicatat bahwa intelijen ini melibatkan gunakan semua yang lain. Seorang individu harus memanfaatkan kecerdasan mereka yang lain untuk sepenuhnya mengekspresikan kecerdasan intrapersonal mereka.

8. Kecerdasan Naturalis. Kecerdasan naturalistik terlihat pada seseorang yang mengenali dan mengklasifikasikan spesies flora dan fauna di lingkungan sekitar.Guru dapat menumbuhkan kecerdasan ini dengan menggunakan hubungan di antara sistem spesies, dan kegiatan klasifikasi. Dalam praktik pembelajaran pendidikan jasmani guru bisa memberikan penjelasan tentang gerak dasar yang bisa diambil dari alam. Misalnya bagaimana gerak pohon tertiup angin. Ini bisa melatih kelenturan togok atau otot bagian tubuh atau badan.

Pembelajaran pada jenjang usia sekolah dasar pada dasarnya membutuhkan penunjang seperti pembelajaran kontekstual yang sesuai dengan komponen multiple intellegince yang dimiliki peserta didik. Pembelajaran kontekstual itu sendiri akan memberikan pengalaman belajar yang tidak bisa dilupakan melalui praktik langsung. Peserta didik dapat langsung merasakan bagaimana belajar lebih banyak dari guru pada umumnya. Hal ini menjadi sebuah pengalaman yang membekali peserta didik dalam menghadapi tantangannya untuk selalu bersosialisasi di kehidupan masyarakat untuk menerapkan hidup sehat. Pengalaman belajar secara langsung di luar kelas merupakan guru terbaik bagi peserta didik.

\section{KESIMPULAN}

Artikel ini memberikan gambaran sejumlah strategi bagi guru pendidik jasmani untuk kegaitan belajar mengajar (1) teknik gerak dasar; (2) hubungan antara hidup sehat yang aktif, teori multiple intelligence, dan pembelajaran gerak lokomotor, non lokomotor dan manipulatif, dan (3) pendekatan Multiple Intelligence untuk mengajar dan belajar. Teori Multiple Intelligence menyatukan sumber daya intelektual dan bervariasi yang diberikan kepada peserta didik dan masyarakat dilingkungan sekolah maupun masyarakat umum. Mengintegrasikan teori Multiple Intelligence dengan prinsip-prinsip hidup sehat secara aktif yang dipelajari sebagai cara untuk perencanaan program, penyampaian program, pembelajaran peserta didik, dan untuk memfasilitasi evaluasi pembelajaran yang sesuai dalam program hidup sehat di sekolah dasar.

\section{DAFTAR PUSTAKA}

Andy Anderson \& Ellen Weber (1997) A Multiple Intelligence Approach to Healthy Active Living in High School, Journal of Physical Education, Recreation \& Dance, 68:4, 57-62, DOI: 10.1080/07303084.1997.10604929 
Armstrong T. (2000). Multiple Intelligences in The Classroom, 2nd Edition. Association for Supervision and Curriculum Development, p:155, Virginia, USA

Bumen N. (2005). Okulda Coklu Zeka Kurami. 3. Baski. Ankara: Pegem A Publishing.

Creswell, J. W. (1998). Qualitatif Inquiry and Research Design. Sage Publications, Inc: California

Cifuentes L. and Hughey J. (2003). The Interactive Effects Of Computer Conferencing and Multiple Intelligences On Expository Writing, The Quarterly Rewiew of Distance Education, Volume: 4(1), p:15-30. Texas A \& M Universty.

Handy Susanto (2005). “Penerapan Multiple Intelligences dalam Sistem Pembelajaran”, Jurnal Pendidikan Penabur-No.04/Th.IV/ hlm. 68.

Kumpulan Undang-Undang dan Peraturan Pemerintah RI Tentang Pendidikan, (Jakarta: Departemen Agama RI 2007), hlm. 8.

Samsudin.(2008). Pembelajaran Pendidikan Jasmani Olahraga dan Kesehatan. Jakarta: PT. FajarInterpratama.

S. Shimatul ula (2013). Revolusi Belajar, Yogyakarta: Ar-Ruzz Media.

Sugiarto, dkk (2007). Psikologi Pendidikan, Yogyakarta: UNY Press.

Howard Gadner (2013). Multiple Intelegences, penerjemah Yelvi Andri Zaimur, Jakarta: Daras Books. 